\title{
Life history of the ctenostome bryozoan Flustrellidra hispida in the White Sea
}

\author{
A.Yu. Kvach ${ }^{1}$, M.A. Varfolomeeva ${ }^{1}$, O.N. Kotenko ${ }^{1}$, \\ A.A. Sukhotin ${ }^{2}$, V.A. Kutiumov ${ }^{1}$, A.V. Grischenko ${ }^{3,4}$, \\ A.I. Granovitch ${ }^{1}$, A.N. Ostrovsky ${ }^{1,5,{ }^{*}}$
}

\begin{abstract}
${ }^{1}$ Department of Invertebrate Zoology, Faculty of Biology, Saint Petersburg State University, Universitetskaya nab. 7/9, Saint Petersburg, 199034 Russia.

E-mails: st035173@student.spbu.ru,m.varfolomeeva@spbu.ru, o.kotenko@spbu.ru, st014231@student.spbu.ru,a.granovich@spbu.ru,a.ostrovsky@spbu.ru

${ }^{2}$ White Sea Biological Station, Zoological Institute, Russian Academy of Sciences, Universitetskaya nab. 1, Saint Petersburg, 199034 Russia.E-mail: alexey.sukhotin@zin.ru

${ }^{3}$ Department of Invertebrate Zoology and Aquatic Ecology, Biological Faculty, Perm State National Research University, Bukirev Street 15, GSP, Perm, 614990 Russia.

E-mail: gat1971@mail.ru

${ }^{4}$ A.V. Zhirmunsky National Scientific Center of Marine Biology, Far East Branch, Russian Academy of Sciences, Palchevskogo Street 17, Vladivostok, 690041 Russia.

${ }^{5}$ Department of Palaeontology, Faculty of Earth Sciences, Geography and Astronomy, Geozentrum, University of Vienna, Althanstrasse 14, Vienna 1090, Austria.

E-mail: andrei.ostrovsky@univie.ac.at

*Corresponding author: a.ostrovsky@spbu.ru ; oan_univer@yahoo.com
\end{abstract}

ABSTRACT: The life history of the ctenostome bryozoan Flustrellidra hispida living intertidally on the brown alga Ascophyllum nodosum in the White Sea has been studied for the first time using colony mapping. Statistical analyses of colony composition (zooidal categories, states) encompassed budding, feeding, reproduction, polypide recycling and zooidal dormancy. This enabled documenting colony life and the overall population status at a much better resolution than using traditional methodology. In the ice-free period the colony composition correlated with colony size rather than time of season. F. hispida begins to breed much earlier in the year than all other bryozoan species whose life histories have been studied in the White Sea, and finishes last. Four colony generations co-exist. Young colonies appear in early spring (March) and reproduce in autumn (thus, yielding a daughter generation). Overwintered colonies of those two generations produce larvae whose settlement continues from spring to autumn (October) of the following year, with a break in August. This yields young colonies of daughter and granddaughter generations. Those granddaughter colonies that formed in spring breed in autumn (together with maternal colonies), thus adding a great-granddaughter generation. Maximal colony lifespan is about 2.5 years. Using published data, we compare the $F$. hispida life history traits in different geographical areas and discuss bryozoan life histories in the White Sea.

How to cite this article: Kvach A.Yu., Varfolomeeva M.A., Kotenko O.N., Sukhotin A.A., Kutiumov V.A., Grischenko A.V., Granovitch A.I., Ostrovsky A.N. 2019. Life history of the ctenostome bryozoan Flustrellidra hispida in the White Sea // Invert. Zool. Vol.16. No.4. P.343-360, appendices 1-5. doi: 10.15298/invertzool.16.4.03

KEY WORDS: modular invertebrate, sexual reproduction, life-history, Bryozoa, White Sea.

Paper is dedicated to the memory of A.A. Dobrovolsky.

Статья посвящена памяти А.А. Добровольского. 


\section{Жизненный цикл ктеностомной мшанки Flustrellidra hispida в Белом море}

\section{А.Ю. Квач ${ }^{1}$, М.А. Варфоломеева 1 , О.Н. Котенко ${ }^{1}$, А.А. Сухотин², В.А. Кутюмов ${ }^{1}$, А.В. Грищенко ${ }^{3,4}$, А.И. Гранович ${ }^{1}$, А.Н. Островский ${ }^{1,5}$}

\footnotetext{
${ }^{1}$ Кафедра зоологии беспозвоночных, Биологический факультет, Санкт-Петербургский гос. университет, Университетская наб., 7/9, Санкт-Петербург, 199034 Россия. E-mails:st035173@student.spbu.ru,m.varfolomeeva@spbu.ru,o.kotenko@spbu.ru, st014231@student.spbu.ru,a.granovich@spbu.ru, a.ostrovsky@spbu.ru

${ }^{2}$ Беломорская биологическая станиия, Зоологический институт РАН, Университетская наб., 1, Санкт-Петербург, 199034 Россия. E-mail: alexey.sukhotin@zin.ru

${ }^{3}$ Кафедра зоологии беспозвоночных и водной экологии, Биологический факультет, Пермский гос. наи. университет, ул. Букирева, 15, ГСП, Пермь, 614990 Россия.E-mail: gat1971@таil.ru ${ }^{4}$ Национальный научный центр морской биологии им. А.В. Жирмунского, ДВО РАН, ул. Пальчевского, 17, Владивосток, 690041 Russia.

${ }^{5}$ Department of Palaeontology, Faculty of Earth Sciences, Geography and Astronomy, Geozentrum, University of Vienna, Althanstrasse 14, Vienna 1090, Austria.

E-mail: andrei.ostrovsky@univie.ac.at
}

РЕЗЮМЕ: Жизненный цикл ктеностомной мшанки Flustrellidra hispida, живущей в приливно-отливной зоне Белого моря на водоросли Ascophyllum nodosum был впервые исследован при помощи картирования колоний. Статистический анализ состава колоний (категорий зооидов, их состояний), а именно наличия почек зооидов, питающихся и размножающихся зооидов, а также тех, у кого полипид находился на стадии дегенерации/регенерации или без полипида, позволил задокументировать жизнь колонии, и состояние популяции в целом, со значительно более высоким разрешением, чем традиционные подходы. В период, когда море свободно ото льда, состав колоний не зависит от сезона, а коррелирует с размером колонии. F. hispida начинает размножаться намного раньше, чем все изученные ранее беломорские мшанки и заканчивает последней. Популяция представлена четырьмя поколениями. Молодые колонии появляются ранней весной (предположительно в марте) и размножаются осенью (таким образом, давая начало дочернему поколению). Перезимовавшие колонии двух поколений на следующий год формируют личинок, чье оседание продолжается с весны по осень (октябрь) с перерывом в августе. В результате формируются колонии дочернего и внучатого поколений. Колонии внучатого поколения, что сформировались весной, размножаются осенью (вместе с материнским поколением), давая начало правнучатому поколению. Максимальная продолжительность жизни колонии - 2,5 года. Используя литературные данные, мы сравнили особенности жизненного цикла F. hispida в разных географических точках, и обсудили жизненные циклы мшанок в Белом море.

Как цитировать эту статью: Kvach A.Yu., Varfolomeeva M.A., Kotenko O.N., Sukhotin A.A., Kutiumov V.A., Grischenko A.V., Granovitch A.I., Ostrovsky A.N. 2019. Life history of the ctenostome bryozoan Flustrellidra hispida in the White Sea // Invert. Zool. Vol.16. No.4. P.343-360, appendices 1-5. doi: 10.15298/invertzool.16.4.03

КЛЮЧЕВЫЕ СЛОВА: модульные беспозвоночные, половое размножение, жизненный цикл, Bryozoa, Белое море. 


\section{Introduction}

The life cycle of aquatic modular invertebrates begins with either sexual (larva) or asexual (fragment/dormant stage) propagation followed by growth via iterative asexual budding of modules. Applying data on life cycles to the population level (including the number of generations, their lifespan, terms of reproduction and reproductive strategies) enables describing the respective life histories. In contrast with other modular suspension-feeders such as sponges, colonial cnidarians, kamptozoans, hemichordates and tunicates (see Nielsen, 1989; Ereskovsky, 2010; Deibel, Lowen, 2011; Darling et al., 2012, for reviews), the life histories of bryozoans are known only fragmentarily and superficially. Studies began to be conducted in the early $20^{\text {th }}$ century, but most focused predominantly on gametic/embryo production and larval settlement (Orton, 1914; Marcus, 1926; Gautier, 1962; Ryland, 1963, 1967; Gordon, 1970; Médioni, 1972; Jackson, Wertheimer, 1985; Cancino, 1986; Seed, Wood, 1994) (Appendix 1). Some authors have included data on colony growth, lifespans and the number of generations (Friedl, 1925; Grave, 1930, 1933; Kuznetzov, 1941; Wood, Seed, 1992; Yagunova, Ostrovsky, 2010; Sokolover et al., 2018). Eggleston $(1963,1969,1972)$ studied the life histories of more than 40 bryozoan species, focusing on their colony lifespan, reproductive seasonality and number of generations. This landmark research, however, lacks details on many important aspects, including a rather low resolution when working with overlapping generations (criticized in Nekliudova et al., 2019a). Numerous data on the life history traits are scattered through the literature on various aspects of bryozoan reproduction, both sexual (Pace, 1906; Bonnevie, 1907; Silén, 1945; Mawatari, 1951; Dudley, 1973; Nielsen, 1981; Dyrynda, King, 1982; Hughes, 1987; Ostrovsky, 1998), and asexual (Winston, 1983; Cheetham et al., 2001; O'Dea, 2006; O'Dea et al., 2008, 2010). This information has been reviewed only briefly (Ryland, 1976; Reed, 1991; Seed, Hughes, 1992). The paucity of detailed studies (Borg, 1947; Dyrynda, Ryland, 1982; Cancino, Hughes, 1987; Barnes, Clarke, 1998) (Appendix 1) is particularly disappointing because bryozoans are among the dominating epibenthic groups worldwide.

Recently, the life histories of four cheilostome bryozoans from the White Sea (Kandalaksha Bay) were studied based on the main zooidal activities (feeding, reproduction, zooidal budding and rejuvenation) by mapping their dynamics in the colonies through the ice-free period (Nekliudova et al., 2019a, b; Shevchenko et al., submitted). This approach yielded a much higher resolution in describing the life history parameters, prompting us to apply it to study the life history of the ctenostome bryozoan Flustrellidra hispida. Certain aspects were studied earlier in the English Channel and the Irish Sea (Pace, 1906; Wood, Seed, 1992; Seed, Wood, 1994), and in the Barents Sea (Denisenko, 1990).

Flustrellidra hispida (Fabricius, 1780) (Fig. 1) is an amphiboreal species, widely distributed in the northern Atlantic from the White Sea and Barents Sea to the northwestern coast of France (Hayward, 1985) and from the St Lawrence Gulf to Woods Hole (Gontar, Denisenko, 1989), and in the northern Pacific from the Kuril Islands to Aleutian Islands (Kluge, 1961, 1975; Androsova et al., 1974; Gostilovskaya, 1978; Kubanin, 1997; Grischenko, 1997) and from the Gulf of Alaska down to California (Robertson, 1900).

Colonies comprise sterile and protandrous hermaphrodite zooids incubating non-feeding pseudocyphonautes larva in the modified tentacle sheath (Prouho, 1892; Pace, 1906; Gruhl, 2008, 2009) (Fig. 1A, F, G). Incubation lasts 12 months (Wood, Seed, 1992), followed by larval release and a short swimming period. After settlement, the larva transforms to an ancestrula that starts zooidal budding. Encrusting colonies are loosely attached to substrata, forming thick, lobed, brown to yellowish patches with a "furry" appearance due to dense spines (Fig. 1A). The autozooids are large, roughly quadrangular, oval to hexagonal, convex, arranged in checkered to irregular pattern and separated by deep grooves. The frontal wall is 

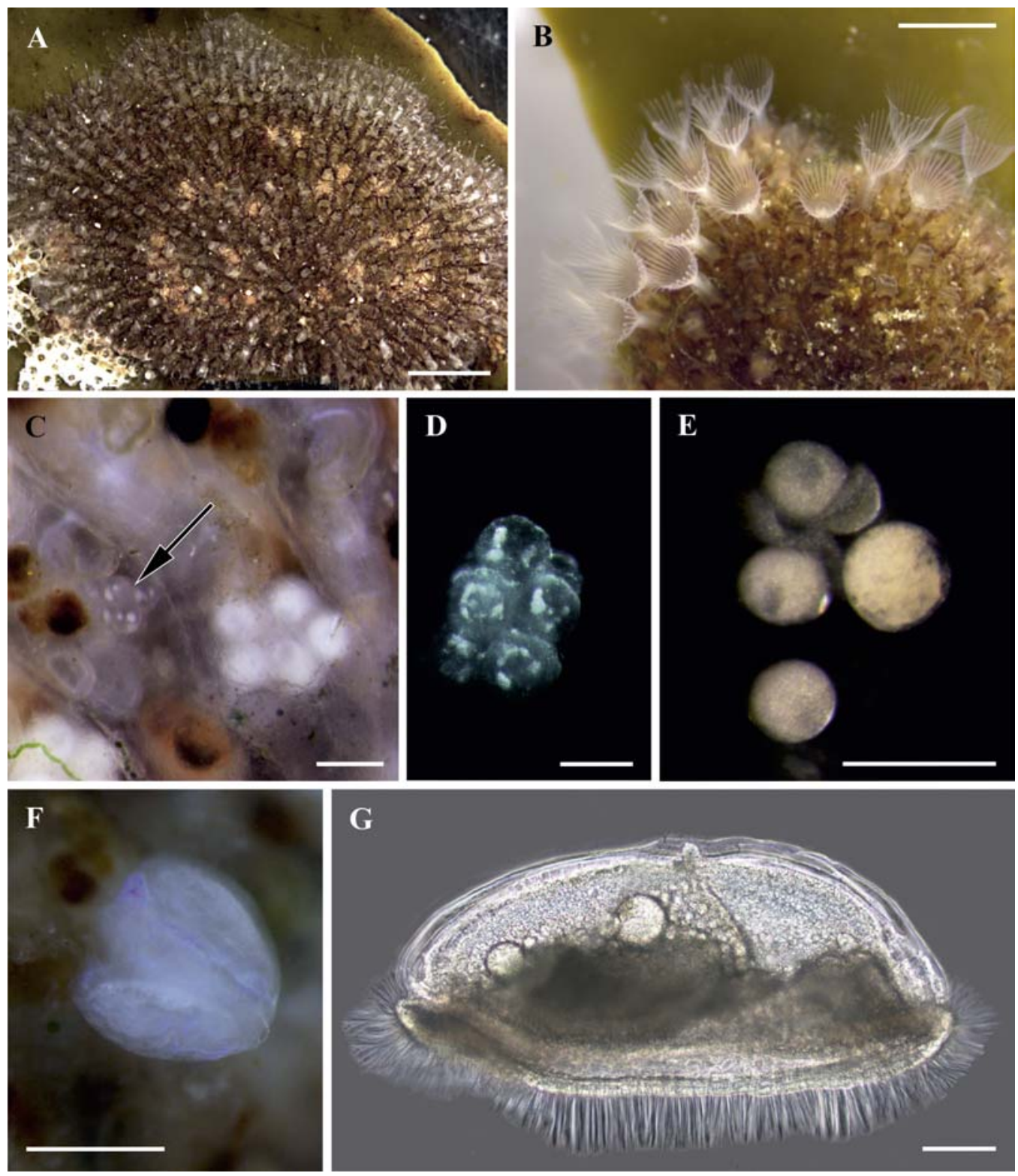

Fig. 1. General view and details of reproduction in Flustrellidra hispida. A - general view of overwintered colony with embryos (light areas); B - feeding autozooids with expanded tentacle crowns; C — basal side of the colony: to the left — zooid with regenerated polypide, "brown body" and early ovary (arrow), to the right - zooid with functional polypide and mature ovary with whitish oocytes visible through transparent zooidal wall; D - early ovary dissected from autozooid; E - late vitellogenic oocytes dissected from autozooid; F - two larvae inside brooding sac dissected from autozooid; $\mathrm{G}$ - released pseudocyphonautes larva. Scale bars: A -2 mm; B -1 mm; C, E $-200 \mu \mathrm{m}$; D, G $-100 \mu \mathrm{m}$; F $-500 \mu \mathrm{m}$.

Рис. 1. Внешний вид и особенности размножения Flustrellidra hispida. А - внешний вид перезимовавшей колонии с эмбрионами (светлые участки); В - питающиеся аутозооиды с расправленными щупальцевыми кронами; $\mathrm{C}$ - базальная сторона колонии: слева виден зооид с регенерировавшим 
smooth, semitransparent, with a subterminal raised orifice. Tentacle number ranges from 28 to 40 (Fig. 1B). Up to 16 large pointed spines arising from blister-like bases are arranged around the distal half of each autozooid (Kluge, 1975; Hayward, 1985). This species inhabits sheltered to moderately exposed rocky shores, preferring middle to lower intertidal horizons and rarely extending to the upper sublittoral. The substrata mostly include brown and red algae. Dense populations can develop in favorable areas.

Having in mind existing data on the life history traits of this species in the warmer waters, our main intention was to compare them with those in the sub-Arctic White Sea. We suggested an existence of potential differences, e.g. in the start and duration of reproduction in different populations. We also compared the life history of $F$. hispida with those of several cheilostomes from the White Sea.

\section{Materials and methods}

Thalli of the brown alga Ascophyllum nodosum with colonies of $F$. hispida were sampled by hand from May to September in 2013, 2015, 2016 and 2017 in the upper subtidal zone of Fettakh Island $\left(66^{\circ} 20.1^{\prime} \mathrm{N}, 33^{\circ} 39.1^{\prime} \mathrm{E}\right)$, in the vicinity of the White Sea Biological Station "Kartesh", Zoological Institute of the Russian Academy of Sciences. Depending on the abundance, 1-10 colonies were randomly collected during each sampling occasion (Appendix 2). Because the preliminary sorting of the thalli was done in the field without a stereomicroscope, the smallest colonies ( $<25$ zooids) were not collected that is explained by their tiny size and transparency. Colonies were fixed in Bouin's fluid, washed in ethanol of increasing concentration (from 40 to $70 \%$ ) and stored in the $70 \%$ ethanol.
In January 2018, colonies were collected under ice (water temperature about $-1^{\circ} \mathrm{C}$ ) to evaluate their state in winter. Some colonies were monitored in aquaria of the "Kartesh" Biological Station (water temperature about $+4{ }^{\circ} \mathrm{C}$ ). Several of these colonies were dissected to determine the state of their zooids. These dissected colonies were not included in statistical analysis because they were destroyed after dissection. The remaining colonies were transported to Saint Petersburg State University and kept in the aquaria of the Resource Center "Environmental Safety Observatory" at $+12{ }^{\circ} \mathrm{C}$ in an attempt to observe their reproduction (the temperature considered optimal for invertebrate reproduction in the White Sea (Kaufman, 1977)).

Each colony was detached from the algal substrate (often by pieces), its basal side was photographed, and zooids were mapped based on polypide state (tentacle crown and associated gut) and the presence of the ovary or embryos (Fig. 1C-F, 2). The following categories were recognized and used for the analysis: (1) young developing zooids (early zooidal buds without polypide rudiment and slightly older zooids having it), (2) zooids with functional polypide, (3) zooids with degenerating polypide, (4) zooids with "brown body" (final stage of polypide degeneration), (5) zooids with "brown body" and regenerating/ed polypide, (6) zooids with functional polypide and ovary (Fig. 1C), (7) zooids with regenerated polypide, "brown body" and ovary (Fig. 1C), and (8) zooids with embryos in the brooding sac (Fig. 1A, F). The total number of zooids and the number of zooids of different categories were counted for each colony (Fig. 2, Appendix 2). Measurements were performed using Image J. Photographs were taken using a Nikon DS-Fi1 microscope attachment for "Leica" DM2500.

Literature data indicate that colonies of different generations and during different periods

полипидом, “бурым телом” и ранним оварием (стрелка), справа зооид с функционирующим полипидом и зрелым оварием, содержащим беловатые ооциты, видимые через прозрачную базальную стенку; D - ранний оварий, извлеченный из аутозооида; Е - поздние вителлогенные ооциты, извлеченные из аутозооида; F — две личинки внутри выводковой сумки, извлеченной из аутозооида; G - псевдоцифонаут, вышедший из колонии. Масштабы: A - 2 мм; B - 1 мм; C, E - 200 мкм; D, $\mathrm{G}$ - 100 мкм; F - 500 мкм. 


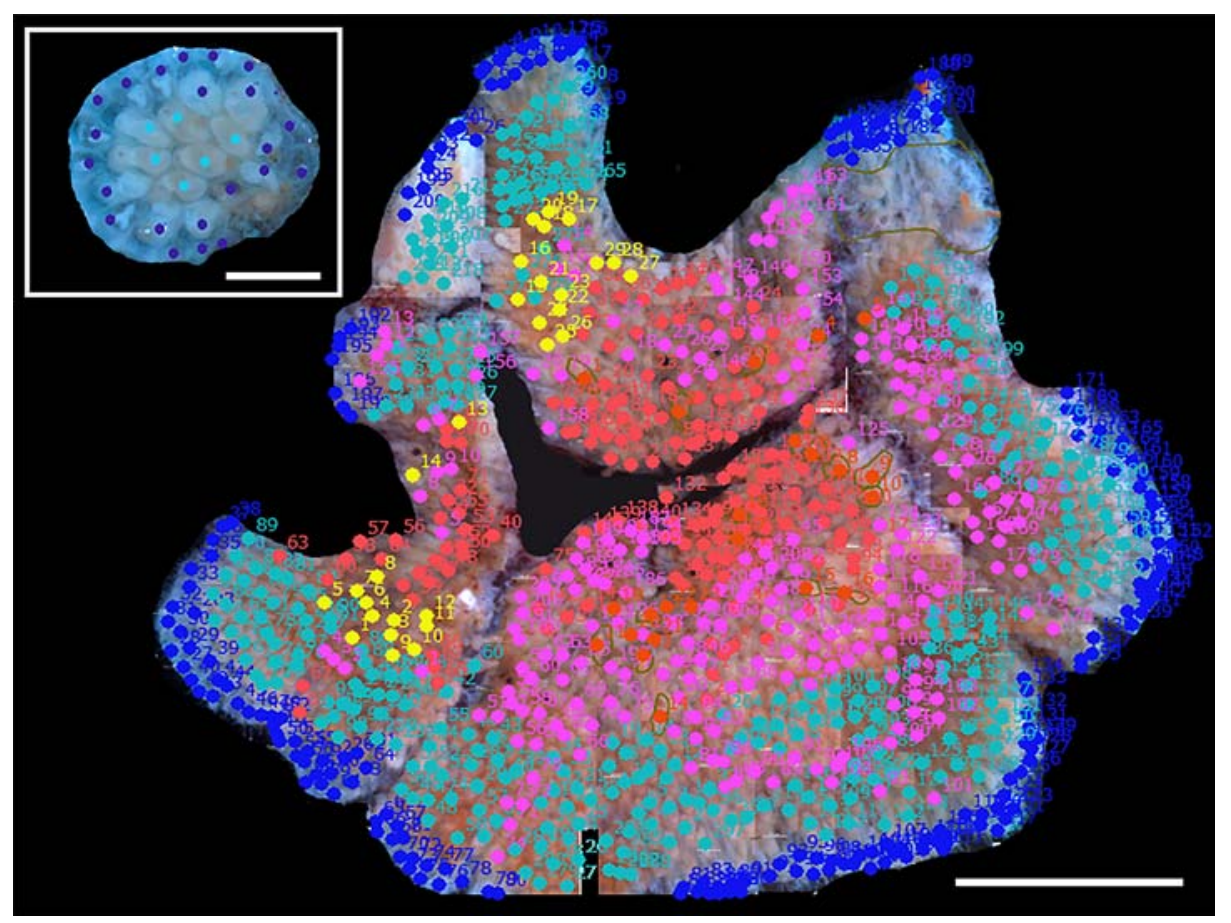

Fig. 2. Mapped colonies of Flustrellidra hispida. Insert - colony younger than 5 months consisting of zooids with functional polypide and zooidal buds (altogether 29). Large colony older than 2 years (908 zooids) cut from algal thallom by pieces and showing zonality in position of zooids. Circles show zooidal categories: blue - young developing zooids (zooidal buds); turquoise — zooids with functional polypide; yellow — zooids with "brown body" and regenerating/ed polypide; pink — zooids with degenerating polypide; red — zooids with "brown body"; orange with brown outline — zooids with embryos. No zooids with ovaries were detected in this colony. Scale bars: young colony $-1 \mathrm{~mm}$; large colony $-5 \mathrm{~mm}$.

Рис. 2. Закартированные колонии Flustrellidra hispida. Вставка - колония моложе 5 месяцев, состоящая из зооидов с функционирующим полипидом и почками зооидов (всего 29). Крупная колония старше 2 лет (908 зооидов), срезанная в виде фрагментов с водоросли. Хорошо видна зональность в расположении зооидов. Кружками разных цветов обозначены разные категории зооидов: голубым - молодые развивающиеся зооиды (почки зооидов); бирюзовым - зооиды с функционирующим полипидом; желтым - зооиды с “бурым телом” и регенерирующим/регенерировавшим полипидом; розовым - зооиды с дегенерирующим полипидом; красным - зооиды с “бурым телом”; оранжевым с бурой окантовкой-зооиды с эмбрионами. Зооидов с овариями в данной колонии отмечено не было. Масштабы: молодая колония -1 мм; большая колония -5 мм.

of the season vary in zooidal composition (proportions of zooids of different categories/states). For example, old colonies generally possess more zooids with the "brown body" and fewer feeding modules (e.g. Nekliudova et al., 2019b). Following this information, we analysed the colony composition of $F$. hispida with the aim of dividing the collected colonies into age groups. Non-metric Multidimensional Scaling
(nMDS; Shitikov, Mastitsky, 2017) was performed using vegan package (Oksanen et al., 2019) in R (R Core Team 2019) on the matrix of Bray-Curtis dissimilarities between colonies, which was computed from percentages of zooidal categories. Vectors indicating the direction of increase of the percentages of zooidal categories were fitted to the ordination. The composition of the colonies depended on colony size, 


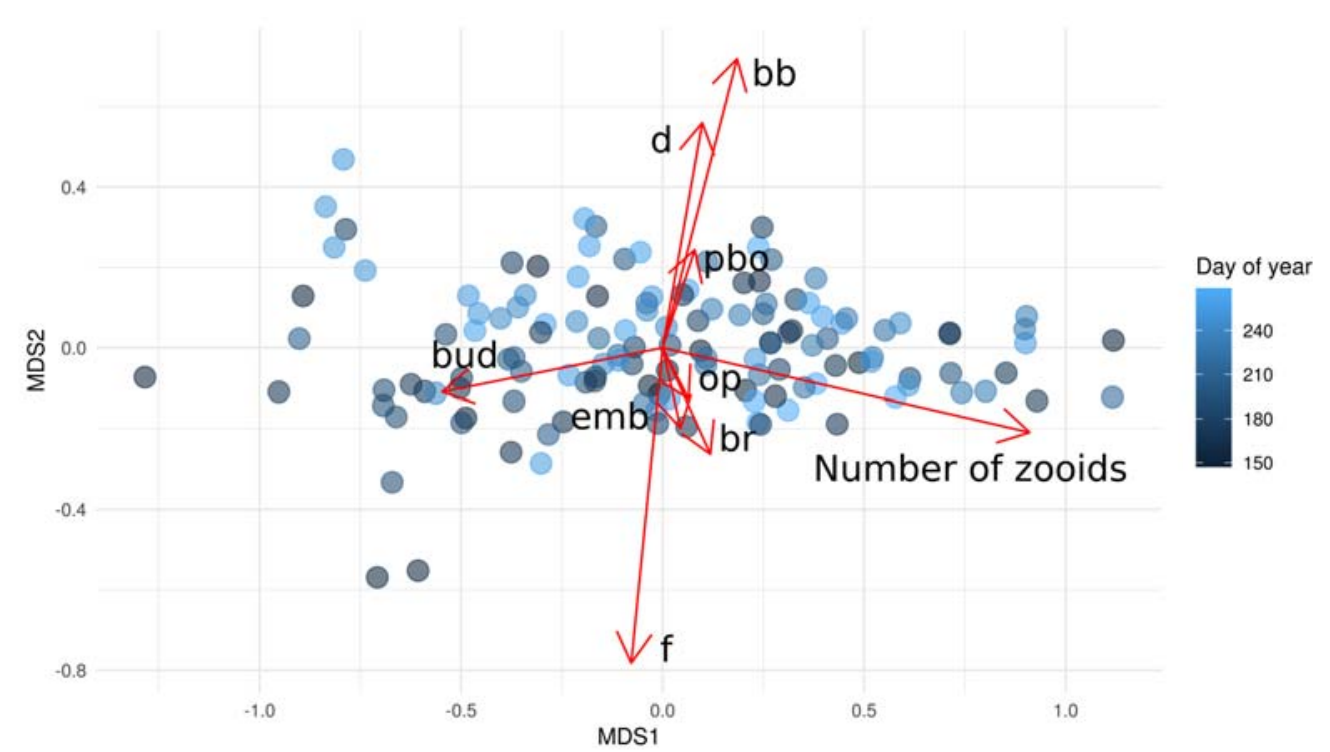

Fig. 3. Similarity between the colonies of Flustrellidra hispida based on their zooidal composition (nonmetric Multidimensional Scaling). The colonies (circles) were collected during the ice-free periods in 20132017. Colour gradient corresponds to sampling date: the darkest blue is day 150 in a year (29 May); the lightest blue is day 266 (23 September). Red arrows are vectors indicating the direction of increase in the value of predictors (percentage of zooids of a certain category). Vector lengths are scaled by their correlation: "weak" predictors have shorter arrows than "strong" predictors. Stress: 0.085.

Abbreviations: bud - young developing zooids (zooidal buds); $\mathrm{f}$ - zooids with functional polypide; $\mathrm{d}$ — zooids with degenerating polypide; $\mathrm{bb}$ - zooids with "brown body"; br — zooids with "brown body" and regenerating/ed polypide; op - zooids with functional polypide and ovary; pbo - zooids with regenerated polypide, "brown body" and ovary; emb - zooids with embryos in brooding sac.

Рис. 3. Сходство между колониями Flustrellidra hispida в зависимости от состава (категорий зооидов) (неметрическое многомерное шкалирование). Колонии (кружки) были собраны с весны на осень в 2013-2017 гг. Цветовой градиент соответствует дате сбора колонии: темно-синий цвет - 150-й день года (29 мая); светло-синий - 266-й день года (23 сентября). Красными стрелками обозначены векторы, указывающие направление увеличения значения предикторов (процентное соотношение зооидов определенной категории). Длины векторов пропорциональны их корреляции, поэтому «слабые» предикторы имеют более короткие стрелки, чем «сильные» предикторы. Стресс: 0,085.

Сокращения: bud - молодые развивающиеся зооиды (почки зооидов); f - зооиды с функционирующим полипидом; d - зооиды с дегенерирующим полипидом; $\mathrm{bb}$ - зооиды с «бурым телом»; br — зооиды с «бурым телом» и регенерирующим/регенерировавшим полипидом; ор - зооиды с функционирующим полипидом и оварием; pbo - зооиды с регенерировавшим полипидом, «бурым телом» и оварием; еmb - зооиды с эмбрионами в выводковой сумке.

not on the date of sampling (i.e. season) (Fig. 3, see below). To distinguish the age groups, we therefore used literature data on the dependence of $F$. hispida colony size (maximal diameter) on age, which were obtained in the Barents Sea by measuring living labeled colonies during their life over ten-day periods (Denisenko, 1990).
To describe the size-age relationship of the bryozoan colonies, Denisenko (1990) used the following equation (exponential function):

$$
L_{t}=L_{0} \cdot e^{g t}
$$

$L_{t}$ - colony diameter (mm) at the age of $t$;

$L_{0}$ - colony diameter (mm) at the age of $0(3.35$ $\mathrm{mm} \pm 0.155$ for $F$. hispida); 
e - base of the natural logarithm;

$\mathrm{g}$ - growth rate $(0.935 \mathrm{~mm} / \mathrm{y} \pm 0.048$ for $F$. hispida);

$\mathrm{t}$ - age (years).

Studied colonies were either roughly circular or oval. Following Denisenko (1990), we measured the maximal (larger) 'diameter' that is a sufficient approximation. Using the formula describing the dependence of size on age, we were able to approximately calculate the size limits for colonies up to one year old (up to 8.44 $\mathrm{mm}$ ), colonies from one to two years (from 8.44 $\mathrm{mm}$ up to $21.25 \mathrm{~mm}$ ), and colonies older than two years $(>21.25 \mathrm{~mm}$ ), assuming constant monotonic growth year round. To determine the age of colonies younger than one year more accurately and thus distinguish the youngest colonies in our samples, we used the data of Wood \& Seed (1992) on the age of the first reproduction of colonies in the Irish Sea (5-6 months). As the water is warmer in there, we suggest that the smallest colony with embryos in our samples ( 77 zooids, $3.74 \mathrm{~mm}$ ) is at least 5 months old in the White Sea, and that all colonies smaller than that are younger than 5 months (Appendix 4).

In order to convert the colony diameter to the number of zooids, we used an independent sample of $F$. hispida colonies which was not involved in the main study. The diameter of each colony was measured and the total number of zooids was calculated (Appendix 3). As a result, a linear regression model was fitted to describe the dependence of colony diameter $(\mathrm{mm})$ on the total number of zooids:

colony diameter $=1.43+0.03 \times$ number of zooids (multiple $\mathrm{R}^{2}=0.92$; see Appendix 3).

Thus, we were able to identify four age/size cohorts. Based on the size of the sampled colonies (diameter and number of zooids), we calculated their age and estimated the average colony size for each age cohort.

Finally, for each age cohort we were able to calculate the average proportion of zooids of each category (average number of zooids in the particular category was divided by the average total number of zooids; Appendix 5).

\section{Results and discussion}

\section{Zooidal states (categories)}

Colony growth in F. hispida occurs gradually by asexual budding of new modules on the colony periphery. This is accompanied by regular changes in the zooidal state, namely by the formation (in the developing zooids), degeneration and regeneration of the polypide and the formation and resorption of the female gonad. In this respect, we have identified eight zooidal categories (states), which allowed us to characterize colonies of different ages based on the differences in the ratio of zooids of different categories (Fig. 2).

(1) Developing zooids are located on the colony periphery, forming a budding zone also known as the growth edge (Fig. 1A, 2, insert). The first stage in the development of a future zooid is the formation of a zooidal bud. When cystid is fully-formed a polypide rudiment is established inside. The latter transforms into a crown of tentacles, surrounded by a tentacle sheath, and associated with a gut. (2) Autozooid with functional polypide is a fully formed module showing no signs of polypide degeneration. The tentacle crown (filtration ciliary apparatus) (Fig. 1B), muscles associated with it and the digestive tract are actively functioning. There are no ovaries or spermatogenic tissue. (3) Zooid with degenerating polypide. It is unable to feed. Being retracted, the polypide is characterized by the loss of the normal appearance of both the intestine and the tentacle crown typical for feeding zooids. Under normal conditions, polypide degeneration (also termed "brown body" formation) is usually associated with aging of the polypide. In some cases, polypide degeneration is coordinated with reproduction cycles, in particular with formation of the gonad and embryonic brooding (Reed, 1991; Dyrynda, Ryland, 1982; Dyrynda, King, 1983; Ostrovsky et al., 2006). (4) Zooid with fully formed "brown body". (5) Zooid with "brown body" and regenerating or regenerated (then functional) polypide. (6) Zooid with functional polypide and ovary, the latter being established in the zooid in association with the bud of the first 
polypide (Fig. 1C). The female gonad is associated with the funiculus connecting the blind part (caecum) of the stomach and the basal wall of the cystid. (7) Zooid with a functioning polypide, "brown body" and ovary (Fig. 1C). This category describes the situation when the first polypide has degenerated, and the "brown body" formed as a result of degeneration remains inside the cystid. A new polypid has been developed, forming an ovary. (8) Zooid with embryos in the brooding sac. The zooid may contain a "brown body", which is resorbed in some cases (Fig. 1F). Zooids with a "brown body" predominantly constitute the centralmost (i.e. the oldest) colony part, being surrounded by a ring zone of zooids with degenerating polypides. The next 'ring' towards the colony periphery is formed by zooids with functioning polypide, followed by peripheral zone of zooidal buds (Fig. 2).

Spermatogenic tissue was found once in our samples (1 June 2013).

During incubation, which lasts 1-2 months, developing embryos grow in the brooding sac; this indicates the presence of extraembryonic nutrition (matrotrophy), which is widely distributed among Bryozoa (Ostrovsky, 2013a,b; Ostrovsky et al., 2009, 2016). Recently, the first ultrastructural evidence of matrotrophic nourishment was obtained for the ctenostome bryozoan Amathia verticillata, which also brood embryos inside a modified tentacle sheath (Schwaha et al., 2019).

\section{Colony composition and its changes} with age

Colony zooidal composition (in terms of zooidal states/categories) is quite variable in June-September, and more stable in January, when all colonies consist of zooids with degenerated polypides, some of which contain ovaries.

The nMDS ordination enabled arranging the colonies depending on their similarity based on the data of their zooidal composition. We were therefore able to evaluate the relationship between zooidal states and the sampling date (Fig. 3).
The four most influential predictors of similarity between colonies were "number of zooids" (colony size), percentage of "zooids with functional polypides", "zooids with degenerating polypides", "zooids with 'brown bodies" " and "young developing zooids". Colonies with a high percentage of zooids with functional polypides have a low percentage of zooids with degenerating polypides or zooids with "brown bodies". The percentage of developing zooids is high in smaller colonies. In bigger ones it decreases as a result of geometrical constraints between colony perimeter and total area (new zooids appear only on the colony periphery in both cases).

We found that colony zooidal composition does not depend on the time in the season (dots of one color do not form groups in Fig. 3), but it strongly depends on colony size. Note, however, that although colony size directly reflects its age, the extremely gradual 'transition' of the colony zooidal composition between the four age cohorts still makes it rather difficult to distinguish them. The average size (Mean \pm $\mathrm{SD})$ of the colonies for each age cohort is following: colonies younger than 5 months is $52 \pm 9.8$ zooids, from 5 months to 1 year $158 \pm 41.8$ zooids, $1-2$ years $-363 \pm 104.3$ zooids, and more than 2 years $-816 \pm 116.8$ zooids.

As colony grows, its zooidal composition changes. Colonies younger than 5 months exhibited only four categories of zooids (Table 1). Reproduction had not started yet and most of the resources were directed to growth - the developing zooids constituted on average about half of all zooids (53.6\%). Zooids with a functioning polypide amounted to $20.9 \%$. No zooids had undergone a cycle of degeneration and regeneration of the polypide yet: on average, only $15.1 \%$ possessed degenerating polypide and $10.3 \%$ of zooids contained a "brown body" (Appendix 5).

Colonies from 5 months to one year old showed certain changes in zooidal composition. Although the percentage of developing zooids was still quite high (37.6\%) in comparison with older colonies, and the number of zooids with degenerating polypides did not increase (14.8\%), 
Table 1. Percentage of zooids of different categories in an average colony. Таблица 1. Доля зооидов (\%) разных категорий в усредненной колонии.

\begin{tabular}{|c|c|c|c|c|c|c|c|c|c|}
\hline $\mathrm{n}$ & age & bud(\%) & $\mathrm{f}(\%)$ & $\mathrm{d}(\%)$ & $\mathrm{bb}(\%)$ & $\mathrm{br}(\%)$ & op(\%) & pbo(\%) & emb(\%) \\
\hline 8 & $<5 \mathrm{~m}$ & 53.60 & 20.9 & 15.14 & 10.30 & 0.00 & 0.00 & 0.00 & 0.00 \\
\hline 54 & $5 \mathrm{~m}-1 \mathrm{y}$ & 37.60 & 28.70 & 14.81 & 12.01 & 3.92 & 0.42 & 0.58 & 1.68 \\
\hline 62 & $1 \mathrm{y}+$ & 29.60 & 23.96 & 18.39 & 17.88 & 5.74 & 0.89 & 1.09 & 2.59 \\
\hline 10 & $2 \mathrm{y}+$ & 20.04 & 17.83 & 22.17 & 26.38 & 7.86 & 1.31 & 0.26 & 4.20 \\
\hline
\end{tabular}

Abbreviations: $\mathrm{n}$ — number of studied colonies of the age cohort; a — age cohort; bud — young developing zooids (zooidal buds); f - zooids with functional polypide; $\mathrm{d}$ - zooids with degenerating polypide; bb — zooids with "brown body"; br — zooids with "brown body" and regenerating/ed polypide; op — zooids with functional polypide and ovary; pbo - zooids with regenerated polypide, "brown body" and ovary; emb - zooids with embryos in the brooding sac.

Сокращения: n - число исследованных колоний, принадлежащих к одной возрастной когорте; а возрастная когорта; bud - молодые развивающиеся зооиды (почки зооидов); f — зооиды с функционирующим полипидом; d - зооиды с дегенерирующим полипидом; bb - зооиды с «бурым телом»; br — зооиды с «бурым телом» и регенерирующим/регенерировавшим полипидом; ор - зооиды с функциональным полипидом и оварием; pbo - зооиды с регенерировавшим полипидом, «бурым телом» и оварием; pbo — зооиды с эмбрионами в выводковой сумке.

zooids with female gonads and embryos appeared $(2.6 \%)$. This means that the resource allocation began to shift from growth to reproduction. Moreover, the proportion of zooids with functioning polypide increased $(29.7 \%$, including those that regenerated their polypide), probably indicating a growing energy demand. Active feeding resulted in a general increase of the proportion of zooids involved in polypide recycling: $3.9 \%$ zooids had polypides that were either undertaking or had already undertaken a cycle of degeneration and regeneration, and $12 \%$ of zooids had «brown bodies» (excluding those with embryos) (Appendix 5).

In the colonies aged 1-2 years, the proportion of zooids with ovaries and zooids with embryos further increased (about 2 and 2.6\%, respectively). In contrast, the percentage of young developing zooids continued to decline (29.6\%). Also, the proportion of zooids with functioning polypide (including those that regenerated their polypide) began to decline (25\%); considering the large size of the colonies, however, this still represents one quarter of the total zooidal number. The percentage of zooids with degenerating polypide, zooids with "brown body" and zooids with a "brown body" and regenerating/ed polypide increased (18.3, 17.8 and $5.7 \%$ ), partially as consequence of active feeding and partially indicating the start of ageing (Appendix 5).

In the colonies older than 2 years, the proportion of zooids with embryos reached a maximum (4.2\%), although the proportion of zooids with ovaries slightly decreased (from 2.0 to $1.5 \%$ ), which indicates a clear transition from oogenesis to brooding. The proportions of young developing zooids and zooids with functioning polypides were the lowest (20 and $19.4 \%$ ), but still accounted for about $40 \%$ of all zooids in a colony; this was accompanied by an increasing percentage of zooids with a "brown body" and regenerating/ed polypide (7.8\%). The percentage of zooids with "brown body" and zooids with degenerating polypide continued to grow (26.3 and $22.1 \%$ ), possibly pointing to ageing (Appendix 5).

In summary, the above-described changes in zooidal composition confirm our interpretation that it correlates with a colony size/age. Colonies aged 1 year and younger put more energy into somatic growth, those older that 1 year into the sexual reproduction. Finally, older colonies have fewer feeding zooids and more zooids with a degenerating polypide and a "brown body" that indicates ageing. 


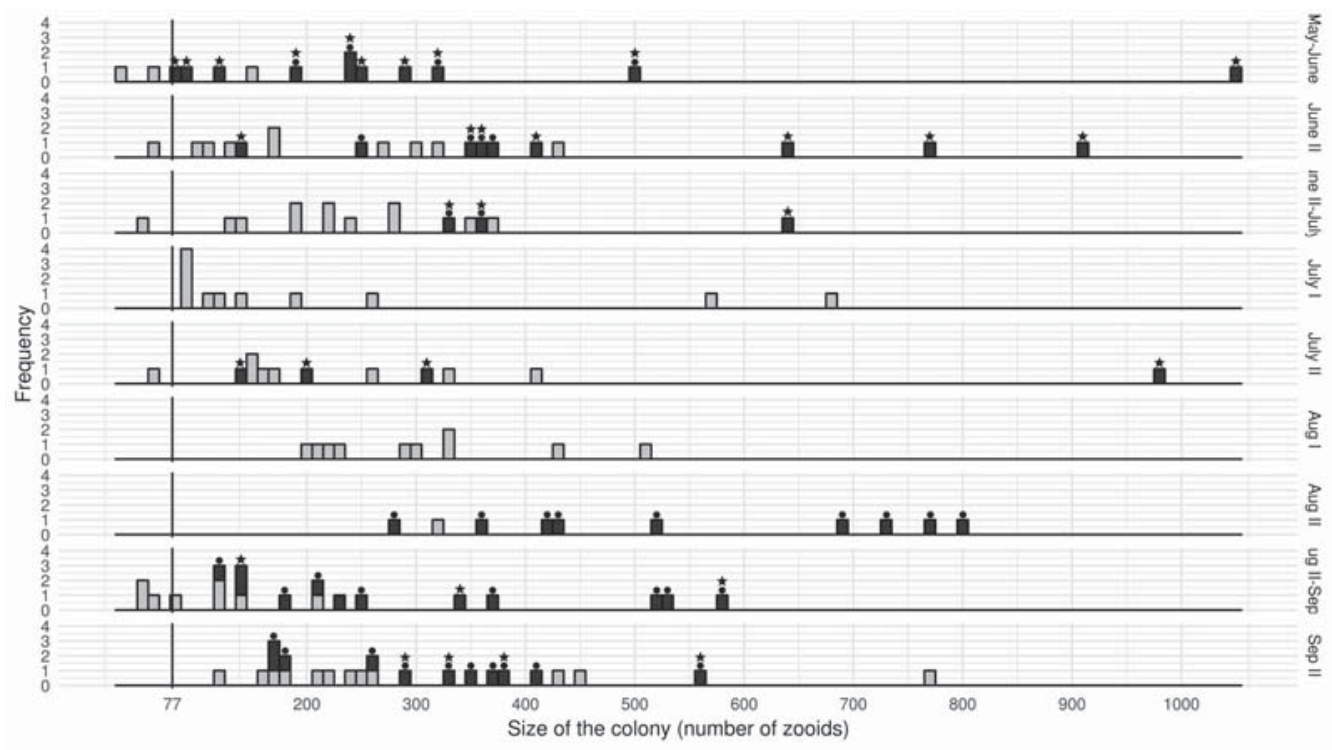

Fig. 4. Frequency of occurrence of differently sized colonies (number of zooids) from June to September. Light gray - colonies without ovaries, black - colonies with ovary. Vertical line - minimal size of a reproducing colony ( 77 zooids). Circles — colonies with ovaries, asterisks - colonies with embryos.

Рис. 4. Частота встречаемости колоний разного размера (измеряется как количество зооидов) с июня по сентябрь. Светло-серый цвет обозначает колонии без яичников, черный - колонии с яичником. Минимальный размер размножающейся колонии (77 зооидов) отмечен вертикальной линией. Кружками обозначены колонии с яичниками, звездочками — колонии с зародышами.

\section{Colony size and reproduction}

In January 2018, all collected colonies had approximately 300 zooids and no functioning polypides. In six of the eight colonies examined, fully formed ovaries (Fig. 1E) were found in addition to the "brown bodies". After incubation at $12{ }^{\circ} \mathrm{C}$ with microalgal food during two months in aquaria, brooded larvae (Fig. 1F) were observed in such colonies in March 2018.

In May-June, the size of the sampled colonies ranged from 29 to 1048 zooids (Fig. 4). Young colonies (29-61 zooids) constituted 8.3\% of all collected colonies. Based on the laboratory observations, we assume that they belonged to the early (spring) cohort, the result of an early spring larval release by overwintered colonies. Embryos were detected in colonies that had reached the minimal size of 77 zooids, and about half of all overwintered colonies (771048 zooids) in May-June contained female gonads or embryos. The decrease in the propor- tion of colonies involved in reproduction during May-June (from $79 \%$ at the beginning of that period to $20 \%$ at its end) was probably due to the formation of larvae and their release. Among breeding colonies $91 \%$ contained embryos in the beginning of this period, and $28.6 \%$ ovaries. Later, at the end of June, the percentage of colonies with embryos decreased to $20 \%$, those with ovaries to $13.3 \%$.

In July (second half), embryos were observed in four colonies only ( $17.4 \%$ of all colonies sampled during that month). Two of them were older than 5 months, one was older than 1 year, whereas the last one approached 2 years. They contained no ovaries.

In July - early August, young colonies were very rare, and they were absent in our samples through the second and the third decades (10 days here and elsewhere) of August. Adult colonies showed an increase in the average colony size from 258 zooids in July to 532 zooids in the 


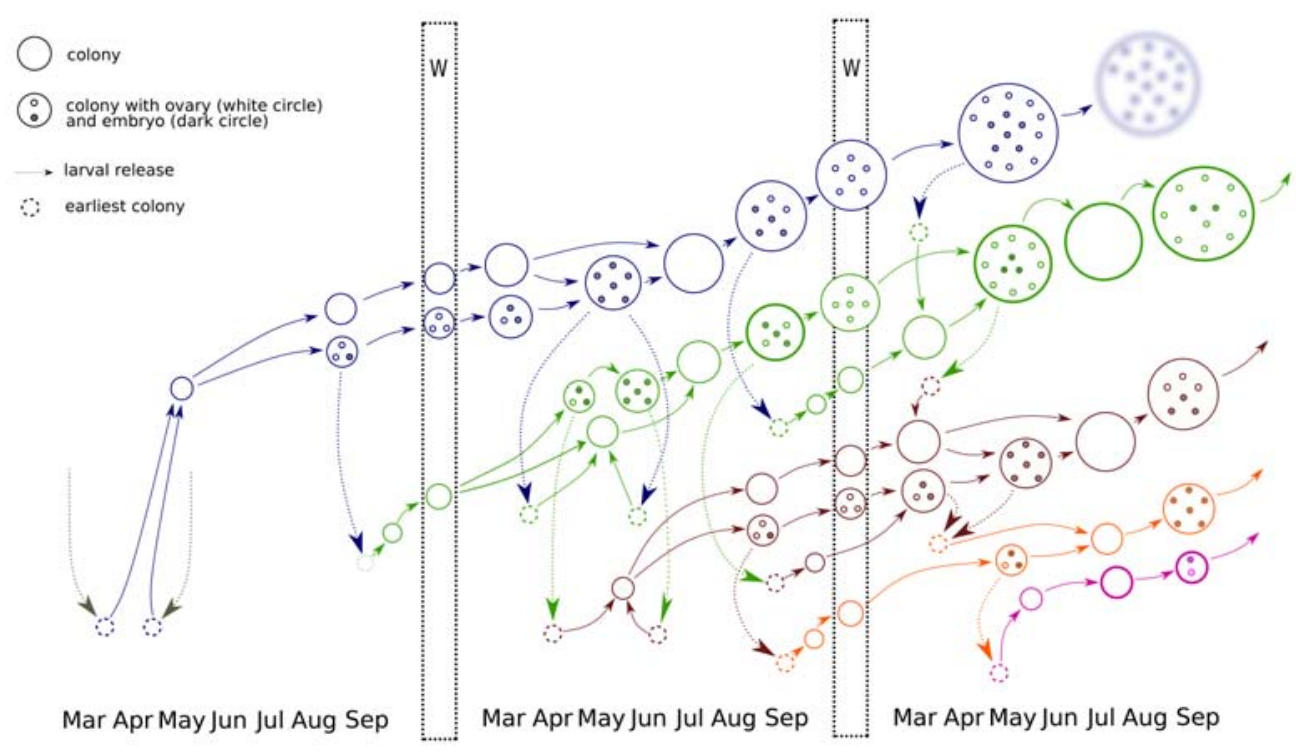

Fig. 5. Schematic representation of the life history of Flustrellidra hispida in the White Sea. Some (but not all) young colonies formed in spring reproduce in September, being 5-6 months old. After overwintering, they produce larvae starting in spring and finishing in autumn (with a possible break in August), overwinter the second time and reproduce again the following year. Their descendants constitute a daughter generation that (partially) breeds in spring-summer and autumn, yielding a granddaughter generation. Its early colonies formed in spring could reproduce in autumn, thus yielding a great-granddaughter generation.

Abbreviations: months from March to September-October; w - period from November to February (winter).

Рис. 5. Схема жизненного цикла Flustrellidra hispida в Белом море. Молодые колонии, сформированные весной, способны размножаться в сентябре (хотя, по-видимому, не все), достигнув возраста 5-6 месяцев. После зимовки они формируют личинок с весны и до осени (предположительно с перерывом в августе), зимуют второй раз и участвуют в размножении еще раз на следующий год. Их потомки образуют дочернее поколение, которое (частично) размножается весной-летом и осенью, давая начало внучатому поколению. Его ранние колонии, сформированные весной, размножаются осенью, давая начало правнучатому поколению.

Сокращения: месяцы с марта по сентябрь-октябрь; w - период с ноября по февраль (зима).

second decade of August (Fig. 4). No colonies with ovaries were encountered during all of July and the first half of August. In contrast, during the second half of August, $80 \%$ of the colonies contained female gonads. Colonies with embryos were encountered in late August only. Two of them were relatively small (140 and 144 zooids). The smallest colony with ovary consisted of 116 zooids.

Young colonies were detected again in early September. These are, apparently, the late colony cohort - the result of the larval release in July.
In September, $42.4 \%$ of the collected colonies were involved in breeding. Of those, $24.4 \%$ contained only ovaries, $3 \%$ - only embryos, and $15 \%$ contained both ovaries and embryos.

\section{Reconstruction of the life history of Flustrellidra hispida}

Based on our collected material and the colonies reared in aquaria, we reconstructed the life history of F. hispida in the White Sea (Fig. 5 ). The maximum colony lifespan can apparently reach about 2.5 years. Generations overlap and repeatedly breed during their life, which is 
consistent with observations in the Menai Strait, North Wales (Wood, Seed, 1992). Those authors described inter-annual fluctuations in terms of reproduction; therefore, because our data have been compiled for several years, the terms of reproduction we describe in our reconstruction are approximations.

Because the pseudocyphonautes larvae are non-feeding and short-lived, their release coincides with settlement. Two mass larval releases take place, i.e. in spring-summer (March-July) and autumn (September). The growth rate of the young colonies is reportedly low during 20-25 days in the spring cohort in the Barents Sea (Denisenko, 1990). In contrast, Eggleston(1972) mentioned rapid growth after settlement of $F$. hispida in the Irish Sea, but since the water is much warmer there we doubt that these data can be applied to the White Sea. We assume that approximately 1-2 months are needed after larval settlement (e.g. in March-April) to form colonies of the early (spring) cohort of about 30 zooids - the size of the smallest colonies we collected in May. This conclusion corresponds to the fact that the small colonies that appeared in early September should be a late (early autumn) cohort - the result of the larval release in late July, reaching similar size in $1-1.5$ months as well. We admit that in a warmer water the colony growth in August could be faster than in spring, and more data are needed to check our suggestion on the colony growth rate in this species.

Colonies formed during spring, summer and early September feed, grow and prepare for overwintering. Those from the early (spring) cohort reach 5-6 months age in September. Some of them form ovaries and embryos, thus participating in the autumn reproduction (and thus producing a daughter generation) together with their (grand)parental colonies. The rest of the 'early' colonies and the 'late' (summer) colonies supposedly remain sterile until the following spring-summer. After overwintering spermiogenesis presumably starts in early spring and continues until June (we encountered it only once, on 1 June 2013). In spring - first half of summer, both the maternal and daughter colonies continue to grow and form oocytes and embryos (from March to July), the latter forming a granddaughter generation. Some large colonies (up to 427 zooids) were not reproducing in June, however, corresponding to observations by Wood \& Seed (1992).

Based on the absence of colonies with ovaries during July and the first half of August and the lack of embryos during almost entire August in our samples (2013 and 2016), we suggest that there is a break in breeding during this period. Four colonies with embryos found in the second half of July could be the remnants of breeding in June. It is potentially possible that our samples were not large enough to 'fill' this gap, although two reproductive cycles were recently described in the cheilostome bryozoan Electra pilosa in the White Sea (Shevchenko et al., submitted). Also, immature embryos were detected in $F$. hispida colonies in October in the Menai Strait, suggesting 'repeated' (although not necessarily 'interrupted') breeding in the individual colonies with prolonged larval production (Wood, Seed, 1992).

In any case, after reaching an age of about 1.5 years, the colonies in our studied population continued reproduction in late August - September and, possibly, later on, together with their daughter colonies (except the latest). Should 'interrupted' breeding take place, it would be accompanied by a new cycle of spermiogenesis. The early granddaughter colonies formed in spring could potentially breed in autumn too, yielding a great-granddaughter generation.

Most of the maternal colonies do not survive the second winter, but those that do survive grow and breed (including spermiogenesis) during their third spring and summer. Thus, the largest recorded colony collected in May (1048 zooids) contained six zooids with ovaries, 38 zooids with ovaries and "brown bodies", and 25 zooids with embryos. Such colonies of about 1000 zooids die in late August (we never encountered them in September) at the age of two and a half years.

Our data largely correspond to the published information on this species elsewhere. According to Pace (1906), who studied F. hispida on the south coast of South Wales, the reproductive 
period starts in early February and continues until early August. In this region, spermiogenesis began earlier in protandric hermaphroditic zooids, being recorded in February and March, although the first young oocytes in the colonies were also detected in February. In March, some colonies contained sperm, eggs, embryos and forming larvae at the same time. No sperm was detected after March, whereas oogenesis and larval brooding progressed. Maximal numbers of young embryos were detected from April to June. In July and August, advanced larvae were still abundant, while oogenesis and early embryogenesis declined. Thus, larval release and settlement occur from April (possibly even late March) to early August (Pace, 1906). Hayward (1985), however, mentions a period from April to early July.

Eggleston $(1963,1969,1972)$ stressed that reproduction takes place in colder months in this species in the Irish Sea (Isle of Man). He recorded the presence of sperm in zooids in November-December and early oocytes in February. Embryos were mentioned in his 1969 and 1972 papers from February to June-July, and from March to June in his $1963 \mathrm{PhD}$ thesis. Depending on warmer or colder summers, larvae and ancestrulae were noted either from March to June or from April to July, respectively (Eggleston, 1963, 1972).

In the Menai Strait, North Wales, embryonic incubation started from February-April in different years, and the larval release continued from March to September or from May to November(Wood, Seed, 1992; Seed, Wood, 1994). Hayward (1985) mentioned a period from May to August in this area.

Despite the differences in the start and the final of reproduction period, which can be clearly explained by climatic differences, the general picture is similar. The sequence of stages in the life cycle starts from spermiogenesis during 1-2 colder months (a negative correlation between sperm production and higher water temperature was recently shown in a cheilostome bryozoan from the Mediterranean Sea (Sokolover et al., 2018)), with oogenesis starting about one month later. The oocytes mature in one month, followed by brooding that lasts 12 months. Larval release begins gradually and, after a summer peak, declines towards winter. Its entire duration is 6-7 months. We suggest that reproduction in the White Sea has two phases - from March to July and from late August to, possibly, October.

\section{Bryozoan life histories in the White Sea}

The bryozoan fauna of the White Sea is represented by 144 nominal species (Gostilovskaya, 1978). The life history has been reconstructed for four cheilostome species coexisting on kelps and red algae (Nekliudova et al., 2019a, b; Shevchenko et al., submitted). In our study we used a similar methodology, which enabled a direct comparison of results. In contrast with the species studied, the ctenostome Flustrellidra hispida was collected intertidally, unlike the aforementioned cheilostomes, which were sampled at 5-10 $\mathrm{m}$ depth.

Cribrillina annulata and Callopora craticula start reproduction in May, and complete it mostly in August - early September and late September, respectively. That probably explains why four generations were detected during the ice-free period in the latter species, and three in the former. Reproduction of Celleporella hyali$n a$ and Electra pilosa starts in June. The former species continues it in September, exhibiting four generations, whereas the latter stops reproduction in August and has three. Note, however, that in all these species the overwintered colonies were arbitrarily considered to be a single/common maternal generation, which artificially simplified the situation. In the case of $F$. hispida the overwintered colonies were shown to be represented by two generations in the current study. Its colonies begin to breed much earlier than the above-described species, and its larval production, possibly, ceases last. During one year, four overlapped generations were detected.

In comparison with the discussed cheilostomes, F. hispida is a long-lived species, with the oldest colonies reaching 30 months versus 13 months in E. pilosa, 15 months in C. crati- 
cula and C. hyalina, and 17 months in C. annulata. It should be stressed, however, that the colony lifespan could be dependent on the algal substrate longevity that is much shorter in kelps (Saccharina latissima species-complex) than in Ascophyllum (see Nekliudova et al., 2019b for detailed discussion).

Eggleston (1972, p. 32) classified F. hispida together with "annuals and biennials", although it could also be placed among perennials. We suggest that the shorter lifespan of the studied cheilostomes is compensated by their ability to quickly start reproduction by very young colonies sized 7-10 zooids. Importantly, in three of the four cheilostome bryozoans the reproduction of each colony is continuous, whereas it is "two-phased" in E. pilosa - the overwintered (maternal) colonies breed twice in summer, while the daughter colonies do so once. Twophase reproduction seemingly occurs in F. hispida. Comparing its life history in warmer waters, it is tempting to explain the two reproduction cycles by the much cooler conditions in the White Sea, where spermiogenesis is timed to relatively low temperatures. This could trigger the breeding cycle at the second time, when summer temperature start to decrease.

Similar to some other bryozoans, the colony size of $F$. hispida affects its ability to form gametes, while for some other species this is not the case and they can start reproduction at very small sizes (see Nekliudova et al., 2019b for further details and discussion). On the other hand, the reproductive periods and lifespans of the species that are able to start reproduction early, are shorter than those in F. hispida, thus demonstrating another effective strategy for survival. Finally, our study indicates that in the ice-free period the colony composition in $F$. hispida does not depend on the time of the season, but rather correlates with colony size. This contradicts the data on C. annulata, for example, in which both old and most young colonies ceased reproduction in August, irrespective of their size (Nekliudova et al., 2019b). In general, the above comparison underlines the diversity of life history traits in species having similar life cycle and often inhabiting similar econiches (e.g. algal substrates), but still using different adaptive trajectories.

\section{Funding}

This study was funded by the Saint Petersburg State University (grants 1.38.233.2015 and 1.42.1493.2015) (field collecting and material processing) and the Russian Science Foundation (grant 18-14-00086) (statistical analysis).

\section{Compliance with ethical standards}

CONFLICT OF INTEREST: The authors declare that they have no conflict of interest.

ETHICAL APPROVAL: No ethical issues were raised during our research.

SAMPLING AND FIELD STUDIES: No permits for sampling and field studies were required.

\section{Supporting Information}

Additional Supporting Information may be found online.

Appendix 1. Methodology applied to the studies on the bryozoan life histories: historical overview.

Appendix 2. Raw data on colony composition in Flustrellidra hispida.

Appendix 3. Colony diameter and the number of zooids in Flustrellidra hispida.

Appendix 4. Colony composition of Flustrellidra hispida. Raw data, summary statistics and colony diameter value.

Appendix 5. The average proportion of zooids of each category in the colonies of Flustrellidra hispida of each age (colonies younger than 5 months, from 5 months to 1 year, 1-2 years, more than 2 years).

\section{Acknowledgments}

This study was performed using the laboratories and equipment of the White Sea Biological Station, Zoological Institute of the Russian Academy of Sciences, Educational and Research Station "Belomorskaia", Saint Petersburg State University and the Centre for Molecular and Cell Technologies, Saint Petersburg State University. Mr S.V. Bagrov, Saint Petersburg State 
University, kindly helped us with collecting. We thank Dr M. Stachowitsch, University of Vienna, for linguistically revising an early draft of the manuscript. We are also deeply indebted to anonymous reviewers who helped to improve the manuscript.

\section{References}

Androsova E.I., Gostilovskaya M.G., Izyumova E.A. 1974. [Phylum Podaxonia, Class Bryozoa. Faunal list of the intertidal of the Kuril Islands] // A.V. Zhirmunsky (ed.). Rastitel'niy i zhivotniy mir litorali Kuril'skikh ostrovov. Novosibirsk: Nauka. P.368-369 [in Russian].

Barnes D.K.A., Clarke A. 1998. Seasonality of polypide recycling and sexual reproduction in some erect Antarctic bryozoans // Mar. Biol. Vol.131. P.647-658.

Borg F. 1947. Zur Kenntnis der Ökologie und des Lebenszyklus von Electra crustulenta // Zool. Bidr. Uppsa1a. Bd.25. S.344-377.

Cancino J.M. 1986. Marine macroalgae as a substratum for sessile invertebrates: a study of Celleporella hyalina (Bryozoa) on fronds of Laminaria saccharina (Phaeophyta)// Monogr. Biol. Vol.4. P.279-308.

Cancino J.M., Hughes R.N. 1987. The effect of water flow on growth and reproduction of Celleporella hyalina (L.) (Bryozoa: Cheilostomata) // J. Exp. Mar. Biol. Ecol. Vol.112. P.109-131.

Cheetham A.H., Jackson J.B., Sanner J. 2001. Evolutionary significance of sexual and asexual modes of propagation in Neogene species of the bryozoan Metrarabdotos in tropical America // J. Paleontol. Vol.75. No.3. P.564-577.

Darling E.S., Alvarez-Filip L., Oliver T.A., McClanahan T.R., Côté I.M. 2012. Evaluating life history strategies of reef corals from species traits // Ecol. Lett. Vol.15. No.12. P.1378-1386.

Deibel D., Lowen B. 2011. A review of the life cycles and life-history adaptations of pelagic tunicates to environmental conditions // ICES J. Mar. Sci. Vol.69. No.3. P.358-369.

Denisenko N.V. 1990. [Distribution and ecology of bryozoans of the Barents Sea]. Apatity: Karelsky Nauchniy Tsentr AN SSSR. 149 p. [In Russian]

Dudley J.E. 1973. Observations on the reproduction, early larval development, and colony astogeny of Conopeum tenuissimum (Canu)// Chesapeake Sci. Vol. 14.P.270278.

Dyrynda P.E.J., Ryland J.S. 1982. Reproductive strategies and life histories in the cheilostome marine bryozoans Chartella papyracea and Bugula flabellata // Mar. Biol. Vol.71. P.241-256.

Dyrynda P.E.J., King P.E. 1983. Gametogenesis in placental and nonplacental ovicellate cheilostome Bryozoa // J. Zool. Vol.200. P.471-492.

Eggleston D. 1963. The marine Polyzoa of the Isle of Man. PhD Thesis. Liverpool: University of Liverpool. 297 p.
Eggleston D. 1969. Marine fauna of the Isle of Man: revised lists of phylum Entoprocta (= Kamptozoa) and phylum Ectoprocta (= Bryozoa) // Rep. Mar. Biol. Stat. Port Erin. Vol.81. P.57-80.

Eggleston D. 1972. Patterns of reproduction in the marine Ectoprocta of the Isle of Man // J. Nat. Hist. Vol.6. P.31-38.

Ereskovsky A.V. 2010. The comparative embryology of sponges. Dordrecht, Heidelberg, London, New York: Springer. $382 \mathrm{p}$.

Fabricius O. 1780. Fauna Groenlandica, systematice sistens animalia Groenlandiae occidentalis hactenus indagata. Hafniae et Lipsiae: I.G. Rothe. 452 p.

Friedl H. 1925. Kolonienbildung, Besiedelung und Wachstum bei marinen Bryozoen // Arb. Zool. Inst. Univ. Innsbruck. Bd.2. S.39-168.

Gautier Y.V. 1962. Recherches écologiques sur les Bryozoaires chilostomes en Méditerranèe Occidentale // Rec. Trav. Stat. Mar. d'Endoume. Vol.39. P.1-434.

Gontar V.I., Denisenko N.V. 1989. Arctic Ocean Bryozoa // Y. Herman (ed.). The Arctic seas. Climatology, oceanography, geology, and biology. New York: Van Nostrand Reinhold Company. P.341-371.

Gordon D.P. 1970. Reproductive ecology of some northern New Zealand Bryozoa // Cah. Biol. Mar. Vol.11. P.307-323.

Gostilovskaya M.G. 1978. [Identification keys to bryozoans of the White Sea]. Leningrad: Nauka. 248 p. [In Russian]

Grave B.H. 1930. The natural history of Bugula flabellata at Woods Hole, Massachusetts, including the behavior and attachment of the larva // J. Morphol. Vol.49. P.355-383.

Grave B.H. 1933. Rate of growth, age at sexual maturity, and duration of life of certain sessile organisms, at Woods Hole, Massachusetts // Biol. Bul. Vol.65. P.375-386.

Grischenko A.V. 1997. [Bryozoans (Ctenostomida, Cheilostomida) of the Commander Islands shelf zone] // A.V. Rzhavsky (ed.). Donnaya flora i fauna shelfovoi zony Komandorskikh ostrovov. Vladivostok: Dalnauka. P.153-192 [in Russian with English summary].

Gruhl A. 2008. Muscular systems in gymnolaemate bryozoan larvae (Bryozoa: Gymnolaemata) // Zoomorphology. Vol.127. No.3. P.143-159.

Gruhl A. 2009. Serotonergic and FMRFamidergic nervous systems in gymnolaemate bryozoan larvae // Zoomorphology. Vol.128. No.2. P.135-156.

Hayward P.J. 1985. Ctenostome bryozoans // Syn. British Fauna. Vol.33. P.1-169.

Hughes D.J. 1987. Gametogenesis and embryonic brooding in the cheilostome bryozoan Celleporella hyalina // J. Zool. Vol.212. P.691-711.

Jackson J.B.C., Wertheimer S.P. 1985. Patterns of reproduction in five common species of Jamaican reefassociated bryozoans // C. Nielsen, G. Larwood (eds.). Bryozoa: Ordovician to recent. Fredensborg: Olsen \& Olsen. P.161-168.

Kaufman Z.S. 1977. [Features of sexual cycles of the White Sea invertebrates]. Leningrad: Nauka. 265 p. [In Russian] 
Kluge G.A. 1961. [Species list of Bryozoa of the Far Eastern seas of the USSR] // Issledovaniya dalnevostochnykh morei SSSR. Vol.7. P.118-143 [in Russian].

Kluge G.A. 1975. [Bryozoa of the northern seas of the USSR] // Opredeliteli po faune SSSR, izdavaemye Zool. Inst. AN SSSR. No.76. 711 p. [In Russian]

Kubanin A.A. 1997. [Phylum Tentaculata, Subphylum Bryozoa] // O. Kussakin, M. Ivanova, A. Tsurpalo (eds.). Spisok vidov zhivotnykh, rasteniy i gribov litorali dal'nevostochnykh morei Rossii. Vladivostok: Dalnauka. P.119-125 [in Russian].

Kuznetzov V.V. 1941. [Dynamics of the biocenosis of Microporella ciliata in the Barents Sea] // Trudy Zool. Inst. AN SSSR. Vol.7. P.114-139 [in Russian with French summary].

Marcus E. 1926. Bryozoa // G. Grimpe, E. Wagler (Hrsg.). Die Tierwelt der Nord und Ostsee. Leipzig: AVG. Bd.4. S.1-100.

Mawatari S. 1951. The natural history of a common fouling bryozoan, Bugula neritina (Linnaeus) // Misc. Rep. Res. Inst. Nat. Res. Tokyo. Vol.20. P.47-54.

Médioni A. 1972. Les peuplements sessile des fonds rocheux de la region de Banyuls-sur-Mer: AscidiesBryozoaires (Premiere partie) //Vie Milieu. B. Vol.21. P.591-656.

Nekliudova U.A., Schwaha T.F., Kotenko O.N., Gruber D., Cyran N., Ostrovsky A.N. 2019a. Sexual reproduction of the placental brooder Celleporella hyalina (Bryozoa, Cheilostomata) in the White Sea // J. Morphol. Vol.280. P.278-299.

Nekliudova U.A., Shunkina K.V., Grishankov A.V., Varfolomeeva M.A., Granovitch A.I., Ostrovsky A.N. 2019b. Colonies as dynamic systems: reconstructing the life-history of Cribrilina annulata (Bryozoa) on two algal substrates // J. Mar. Biol. Assoc. UK. Vol.99. No.6. P.1363-1377.

Nielsen C. 1981. On morphology and reproduction of Hippodiplosia insculpta and Fenestrulina malusii (Bryozoa, Cheilostomata) // Ophelia. Vol.20. P.91125.

Nielsen C. 1989. Entoprocts // Syn. British Fauna. Vol.41. P.1-131.

O'Dea A. 2006. Asexual propagation in the marine bryozoan Cupuladria exfragminis // J. Exp. Mar. Biol. Ecol. Vol.335. P.312-322.

O’Dea A., Jackson J.B.C., Taylor P.D., Rodríguez F. 2008. Modes of reproduction in recent and fossil cupuladriid bryozoans // Palaeontology Vol.51. P.847-864.

O’Dea A., Ostrovsky A.N., Rodrígues F. 2010. Embryonic brooding and clonal propagation in tropical eastern Pacific cupuladriid bryozoans // J. Mar. Biol. Assoc. UK. Vol.90. P.291-299.

Oksanen J., Blanchet F.G., Friendly M., Kindt R., Legendre P., McGlinn D., Minchin P.R., O'Hara R.B., Simpson G.L., Solymos P., Stevens M.H.H., Szoecs E., Wagner H. 2019. vegan: Community Ecology Package. R package version 2.5-5. https://CRAN.R-project. org/package $=$ vegan

Orton J.H. 1914. Preliminary account of a contribution to an evaluation of the sea // J. Mar. Biol. Assoc. UK. Vol.10. P.312-326.
Ostrovsky A.N. 1998. Comparative studies of ovicell anatomy and reproductive patterns in Cribrilina annulata and Celleporella hyalina (Bryozoa: Cheilostomatida) // Acta Zool. Vol.79. P.287-318.

Ostrovsky A.N. 2013a. Evolution of sexual reproduction in marine invertebrates: example of gymnolaemate bryozoans. Dordrecht, Heidelberg, New York, London: Springer. $356 \mathrm{p}$.

Ostrovsky A.N. 2013b. From incipient to substantial: evolution of placentotrophy in a phylum of aquatic colonial invertebrates // Evolution. Vol.67. P.13681382.

Ostrovsky A.N., Gordon D.P., Lidgard S. 2009. Independent evolution of matrotrophy in the major classes of Bryozoa: transitions among reproductive patterns and their ecological background // Mar. Ecol. Prog. Ser. Vol.378. P.113-124.

Ostrovsky A.N., Grischenko A.V., Taylor P.D., Bock P., Mawatari S.F. 2006. Comparative anatomical study of internal brooding in three anascan bryozoans (Cheilostomata) and its taxonomical and evolutionary implications // J. Morphol. Vol.267. P.739-749.

Ostrovsky A.N., Lidgard S., Gordon D.P., Schwaha T., Genikhovich G., Ereskovsky A.V. 2016. Matrotrophy and placentation in invertebrates: a new paradigm // Biol. Rev. Vol.91. P.673-711.

Pace R.M. 1906. On the early stages in the development of Flustrellidra hispida (Fabricius), and on the existence of a "yolk nucleus" in the egg of this form // Q. J. Microsc. Sci. Vol.50. P.435-478.

Prouho H. 1892. Contribution a l'histoire des bryozoaires // Arch. Zool. Exp. Gen. Vol.10. P.557-656.

R Core Team. 2019. R: A language and environment for statistical computing. R Foundation for Statistical Computing, Vienna: Austria. https://www.R-project. org/

Reed C.G. 1991. Bryozoa // A.C. Giese, J.S. Pearse, V.B. Pearse (eds.). Reproduction of marine invertebrates Pacific Grove: Boxwood Press. Vol.6: Echinoderms and lophophorates. P.85-245.

Robertson A. 1900. Papers from the Harriman Alaska Expedition. 6. The Bryozoa // Proc. Washington Acad. Sci. Vol.2. P.315-340.

Ryland J.S. 1963. Systematic and biological studies on Polyzoa (Bryozoa) from western Norway // Sarsia. Vol.14. P.1-59.

Ryland J.S. 1967. Polyzoa // Oceanogr. Mar. Biol. Vol.5. P.343-369.

Ryland J.S. 1976. Physiology and ecology of marine bryozoans // Adv. Mar. Biol. Vol.14. P.285-443.

Schwaha T., Moosbrugger M., Walzl M., Ostrovsky, A.N. 2019. First ultrastructural evidence of placental nutrition in a ctenostome bryozoan: example of Amathia verticillata // Zoomorphology. Vol.138. P.221-232.

Seed R., Hughes R.N. 1992. Reproductive strategies of epialgal bryozoans // Invert. Reprod. Dev. Vol.22. P.291-300.

Seed R., Wood V. 1994. Recruitment and mortality of Alcyonidium hirsutum (Fleming) and Flustrellidra hispida (Fabricius) (Bryozoa: Ctenostomata) within a 
Fucus serratus L. community // Cah. Biol. Mar. Vol.35. P.305-326.

Shevchenko E.T., Varfolomeeva M.A., Nekliudova U.A., Kotenko O.N., Granovitch A.I., Ostrovsky A.N. (submitted). Electra vs Callopora: life histories of two bryozoans with contrasting reproductive strategies in the White Sea // Invert. Reprod. Dev.

Shitikov V.K., Mastitsky S.E. 2017. [Classification, regression and other algorithms of data mining using R]. P.351. [Internet resource] https://stok1946.blogspot. com/ (accessed: 24.07.2018) [in Russian].

Sokolover N., Ostrovsky A.N., Ilan M. 2018. Schizoporella errata (Bryozoa, Cheilostomata) in the Mediterranean Sea: abundance, growth rate, and reproductive strategy // Mar. Biol. Res. Vol.14. No.8. P.868-882.
Silén L. 1945. The main features of the development of the ovum, embryo and ooecium in the ooeciferous Bryozoa Gymnolaemata // Ark. Zool. Vol.35. P.1-34.

Winston J.E. 1983. Patterns of growth, reproduction and mortality in bryozoans from the Ross Sea, Antarctica // Bull. Mar. Sci. Vol.33. P.688-702.

Wood V., Seed R. 1992. Reproduction and growth of Alcyonidium hirsutum (Fleming) and Flustrellidra hispida (Fabricius) (Bryozoa: Ctenostomata) within a Fucus serratus L. community // Cah. Biol. Mar. Vol.33. P.347-363.

Yagunova E.B., Ostrovsky A.N. 2010. The influence of substrate type on sexual reproduction of the bryozoan Cribrilina annulata (Gymnolaemata, Cheilostomata). A case study from Arctic seas // Mar. Biol. Res. Vol.6. P.263-270.

Responsible editors K.G. Mikhailov, E.N. Temereva 